Paedagogia Christiana

I/27 (20I I) - ISSN 1505-6872

Anna Seredyńska*

Kraków

\title{
Dojrzałe mechanizmy obronne a potrzeby i wartości preferowane przez przyszłych pedagogów
}

Zawód pedagoga jest niewątpliwie tym, który wymaga szczególnych predyspozycji i umiejętności. Wyzwala też czasami różnorakie mechanizmy w człowieku służące ochronie własnej osoby, własnych granic, a czasami prywatności. Stąd pedagodzy często stosują różne mechanizmy obronne. Niektóre badania wykazały jednak, że szczególnie ważne i skuteczne w pracy wychowawczej są mechanizmy obronne dojrzałe. Stwierdzono na przykład, że pedagodzy charakteryzujący się poczuciem humoru i zadowoleniem ze swojego życia są mniej narażeni na syndrom wypalenia zawodowego ${ }^{1}$.

Niniejszy artykuł ma za zadanie ukazać preferencje wartości, zakres potrzeb psychicznych i mechanizmów obronnych w życiu przyszłych pedagogów. W tym celu określone zostaną istotne różnice w nasileniu potrzeb i preferowaniu wartości przez osoby mające duże nasilenie mechanizmów obronnych dojrzałych oraz mające ich małe nasilenie. Następnie zostaną określone związki pomiędzy nasileniem dojrzałych mechanizmów obronnych i intensywnością potrzeb oraz preferowaniem wartości.

* Dr Anna Seredyńska, adiunkt na Wydziale Pedagogicznym Wyższej Szkoły Filozoficzno-Pedagogicznej „Ignatianum” w Krakowie.

${ }^{1}$ Por. M. Sekułowicz, Nauczyciele szkolnictwa specjalnego wobec zagrożenia wypaleniem zawodowym. Analiza przypadków, Wrocław 2005, s. 77-136. 


\section{Założenia teoretyczne}

Pierwszym krokiem do przedstawienia wyników badań nad znaczeniem mechanizmów obronnych dojrzałych dla przyszłych pedagogów jest wskazanie, czym są mechanizmy obronne oraz czym są potrzeby i wartości, z którymi związek mechanizmów będzie badany.

\subsection{Mechanizmy obronne}

Siek określa mechanizmy obronne jako siły działające w osobowości² Pobudzają one do specyficznych zachowań. Bronią przed wstydem, lękiem, poczuciem winy, obniżeniem dobrego mniemania o sobie we własnych oczach oraz w oczach innych. Pojawiają się, gdy u osoby istnieją jednocześnie dwie sprzeczne ze sobą tendencje do reagowania. Zmniejszają one siły nacisku tych tendencji, otamowują je. Takie sprzeczne tendencje mogą być niezgodne $\mathrm{z}$ kultura, związane $\mathrm{z}$ dezaprobatą bliskich lub też niezgodne $\mathrm{z}$ obrazem samego siebie. Mechanizmy obronne pracują, aby pogodzić ze sobą sprzeczne impulsy.

Mechanizmy obronne są dzielone w różny sposób. Jeden ze sposobów uwzględnia ich zadania rozwojowe i przystosowawcze. Pierwszą grupą są te, których zadaniem jest tamowanie. Mechanizmy tej grupy nie pozwalają popędom na wydobycie się na zewnątrz. Znajdują się tutaj na przykład mechanizmy takie jak wypieranie czy też tłumienie. Kolejna grupa to mechanizmy, których zadaniem jest przemieszczenie. Przenoszą one popędy z jednego obiektu na inny. Należą do nich na przykład sublimacja, przeniesienie czy też kompensacja. Trzecia grupa to mechanizmy powodujące zniekształcenie rzeczywistości. Należą tutaj racjonalizacja i zaprzeczenie. Ostatnią wymienianą grupą są mechanizmy, których zadaniem jest przyjmowanie za swoje cudzych zachowań. Są to na przykład: identyfikacja, inkorporacja, introjekcja czy też konformizm.

Podziałem istotnym dla niniejszego artykułu jest podział mechanizmów obronnych w zależności od stopnia ich dojrzałości. Gabbard stwierdza, iż zadaniem mechanizmów obronnych jest chronienie narcystycznej wrażliwości i poczucia własnej wartości w obliczu wstydu³. Dzieli też mechanizmy obronne na trzy rodzaje: prymitywne, wyższe oraz dojrzałe. W grupie pry-

2 Por. S. Siek, Struktura osobowości, Warszawa 1986, s. 157-214.

${ }^{3}$ Por. G. G. Gabbard, Dlugoterminowa psychoterapia psychodynamiczna, Materiały do użytku wewnętrznego. Krakowskie Centrum Psychodynamiczne, w: http//www.kcp.krakow.pl. 
mitywnych znajdują się takie jak: rozszczepienie, identyfikacja projekcyjna, projekcja, zaprzeczenie, dysocjacja, idealizacja, dewaluacja oraz acting out. W grupie mechanizmów wyższych znajdują się z kolei introjekcja, przemieszczenie, identyfikacja, intelektualizacja, racjonalizacja, reakcja upozorowana, wyparcie i odczynianie. W grupie mechanizmów dojrzałych autor wymienia: humor, ascezę, altruizm, tłumienie oraz sublimację. Kryterium takiego podziału jest czas rozwojowy, kiedy te mechanizmy pojawiają się u człowieka. Na przykład mechanizm rozszczepienia pojawia się w pierwszych miesiącach życia. Jest wtedy normalnym zachowaniem u niemowlęcia. Jednak dla osób dorosłych jest prymitywnym mechanizmem obronnym. Według tej teorii, czym dojrzalszą jest osoba, tym dojrzalszymi mechanizmami obronnymi się posługuje.

W obecnym artykule autorka przyjmuje rozumienie mechanizmów obronnych wprowadzone przez Gabbarda, który określił je jako mające za zadanie chronienie narcystycznej wrażliwości i poczucia własnej wartości w obliczu wstydu ${ }^{4}$.

\subsection{Potrzeby psychiczne}

Badanie mechanizmów obronnych człowieka można umiejscowić w antropologii rozumianej psychodynamicznie. To psychodynamiczna psychologia uwzględnia w rozumieniu człowieka jego nieświadomość. Idąc za tym, opisując potrzeby psychiczne, można skorzystać z definicji H. A. Murraya, który określa je jako hipotetyczne siły o fizykochemicznej naturze, zlokalizowane w mózgu ${ }^{5}$. Potrzeba organizuje percepcję, spostrzeganie, świadome działania i motorykę. Potrzeba jest nie tylko napędem, jak popęd, ale też procesem zapoczątkowującym działanie. Każdy człowiek posiada charakterystyczną dla siebie wiązkę potrzeb. Jedna z nich dominuje, inne zaś są jej podporządkowane.

Według Głaza, powołującego się na analizę egzystencjalną, jedną z ważnych potrzeb u człowieka jest potrzeba sensu życia ${ }^{6}$. Kryterium jej realizacji jest przekraczanie realizowania jedynie potrzeb fizjologicznych. Ta potrzeba jest konsekwentnym dążeniem z wysiłkiem do realizacji celów wykraczających poza zaspokojenie potrzeb fizjologicznych.

${ }^{4}$ Por. tamże.

${ }^{5}$ Por. S. Siek, Struktura, s. 138-156.

${ }^{6}$ Por. S. Głaz, Osobowościowe uwarunkowania przeżyć religijnych, Poznań 2003, s. $52-58$. 
Większość z potrzeb człowieka znajduje ujście w jego zewnętrznym działaniu? ${ }^{7}$. Niektóre jednak, jak podkreślają niektórzy psycholodzy, zostają zatamowane, sthumione i wyparte. Wtedy jako ukryte pojawiają się w postaci gry wyobraźni, w marzeniach, zabawie oraz twórczości artystycznej.

Rulla, odwołując się do teorii Murraya, definiuje potrzebę jako „tendencję do działania wynikającą z braku w organizmie lub z naturalnych wewnętrznych możliwości, które domagają się spełnienia"8. Rulla wyróżnia wśród potrzeb podawanych przez Murraya tak zwane potrzeby rozbieżne 9 . Są to potrzeby, które są związane z brakiem dojrzałości osobowej. Wymienia wśród tych potrzeb następujące: agresji, seksualną, doznawania opieki i oparcia, unikania urazu fizycznego, ekshibicjonizmu, poniżania się i unikania urazu psychicznego.

Autorka artykułu korzysta w badaniach z definiowania potrzeb podanego przez Murraya, który określa je jako hipotetyczne siły o fizykochemicznej naturze, zlokalizowane w mózgu ${ }^{10}$.

\section{Wartości w życiu czlowieka}

Wartości są definiowane wpierw przez filozofów. Scheler stwierdza, iż wartości to nie dobra, cechy, własności rzeczy czy też dyspozycje ${ }^{11}$. Wartości są bytami, które istnieją obiektywnie i nie ulegają zmianie, gdy zmieniają się rzeczy. Poznanie wartości następuje w aktach emocjonalnych preferowania.

Takiemu stawianiu sprawy sprzeciwił się Wojtyła, który stwierdził, iż u Schelera istnieje zbyt duży subiektywizm związany przede wszystkim z emocjonalnym poznaniem wartości. Wojtyła uważa, że człowiek jest sprawcą czynu. Emocje są ważne w poznaniu wartości, ale nie można deprecjonować rozumu i woli. U Schelera w centrum doświadczenia ludzkiego znajduje się wartość, zaś u Wojtyły człowiek doświadczający wartości.

Frankl stwierdza, iż wartość jest powiązana z sensem życia człowieka ${ }^{12}$. Człowiek w rzeczywistości nie podlega jedynie popędom, ale jest również przyciagany przez wartości. Frankl zwraca również uwagę na rolę cierpienia w dojrzewaniu do prawdziwych wartości.

\footnotetext{
7 Por. tenże, Sens życia, Kraków 1998, s. 41-49.

8 S. Morgalla, Dojrzatość osobowościowa i religijna, Kraków 2006, s. 29.

9 Por. L. M. Rulla, Depth psychology and vocation. A Psycho-social Perspective, Rome-Chicago 1983, s. 29-43.

${ }^{10}$ Por. S. Siek, Struktura, s. 138-156.

${ }^{11}$ Por. A. Węrzecki, Scheler, Warszawa 1975, s. 36-72.

12 Por. V. E. Frank1, Homo patiens, Warszawa 1984, s. 27-40.
} 
Jak stwierdza Głaz, powołując się na Frankla, człowiek realizuje się dzięki wartościom ${ }^{13}$. Są one punktami odniesienia ludzkiego życia. Badając wartości, jakie człowiek akceptuje, poznaje się jego widzenie świata, jego skalę ważności.

Rokeach wskazuje, iż hierarchie wartości u człowieka są zbudowane z przekonań nakazujących i zakazujących ${ }^{14}$. W jego teorii jest to jeden z trzech rodzajów przekonań, czyli prostych twierdzeń akceptowanych przez osobę. Pierwsze to przekonania deskryptywne, które można ocenić w kategorii prawdy i fałszu. Następne to przekonania ewaluatywne, oceniające czy czyn jest dobry, czy zły. Ostatnie zaś to przekonania preskryptywne i proskryptywne, czyli właśnie nakazujące i zakazujące.

Rulla, powołując się na Rokeacha, dzieli wartości na takie, które są środkami prowadzącymi do celu i są określane jako instrumentalne oraz takie, które są samymi celami do osiagnnięcia i są określane jako ostateczne ${ }^{15}$. Definiuje on wartości jako ,trwałe, abstrakcyjne ideały osoby, dotyczące idealnych sposobów postępowania i idealnych celów-stanów egzystencji"16.

W badaniach użyto definiowania wartości wprowadzonego przez Rokeacha i ukazującego je jako przekonania nakazujące i zakazujące ${ }^{17}$. Zastosowano też jego podział na wartości ostateczne oraz instrumentalne.

\section{Metodologia badań}

Problemem badawczym postawionym w artykule jest pytanie: Czy mechanizmy obronne dojrzałe mają znaczenie w życiu przyszłych pedagogów? Problemami szczegółowymi zaś są pytania:

- Czy mechanizmy obronne dojrzałe maja istotny zwiazek z intensywnościa potrzeb psychicznych u przyszłych pedagogów? oraz

- Czy mechanizmy obronne dojrzałe maja zwiazek z preferowaniem wartości przez przyszłych pedagogów?

Odpowiedziami na te pytania są następujące hipotezy badawcze:

- Przypuszcza się, ze mechanizmy obronne lacza się ze sfera potrzeb i preferowanych wartości, a przez to moga mieć wptyw na caty obszar działania zawodowego (i nie tylko) przyszłych pedagogów,

${ }^{13}$ Por. S. Głaz, Sens życia, s. 50-55.

${ }_{14}$ Por. P. Brzozowski, Rokeacha „Procedura zmiany wartości”, w: Psychologia matematyczna. III. Metodologiczne problemy psychometrii, Kraków 1989, s. 53-68.

15 Por. L. M. Rulla, dz. cyt., s. 29-43.

${ }^{16}$ S. Morgalla, dz. cyt., s. 30.

${ }^{17}$ Por. P. Brzozowski, dz. cyt., s. 53-68. 
- Podejrzewa się, że mechanizmy obronne dojrzałe maja zwiazek z intensywnościa potrzeb u przyszlych pedagogów oraz

- Zakłada się, że mechanizmy obronne dojrzate maja zwiqzek z preferencja wartości u przyszlych pedagogów.

Zmiennymi w badaniach były mechanizmy obronne, potrzeby oraz wartości instrumentalne i ostateczne. W analizie regresji, która bada konkretny wpływ, zmiennymi zależnymi były mechanizmy obronne dojrzałe, zaś niezależnymi potrzeby i wartości.

Wskaźnikami dla potrzeb były postawy deklarowane przez badanych w Kwestionariuszu Murraya, wskaźnikami dla wartości, wartości deklarowane w Kwestionariuszu Preferencji Wartości Rokeacha, zaś wskaźnikami dla mechanizmów obronnych postawy deklarowane w Kwestionariuszu Poziomu Mechanizmów Obronnych skonstruowanym przez autorkę artykułu.

Metodą badań był sondaż diagnostyczny, techniką ankieta, zaś narzędziami: Kwestionariusz Potrzeb Murraya, Kwestionariusz Preferencji Wartości Rokeacha oraz Kwestionariusz Poziomu Mechanizmów Obronnych stworzony przez autorkę artykułu.

Kwestionariusz Murraya w polskiej wersji został przygotowany pod kierunkiem Sieka przez Skarżyńską-Gawrońską w roku $1974{ }^{18}$. Kwestionariusz służy do badania 19 potrzeb psychicznych. Do kwestionariusza została dołączona 4-punktowa skala.

Kwestionariusz Preferencji Wartości Rokeacha został opracowany przez zakład Psychologii Społecznej i Psychologii Religii KUL. Składa się on z dwóch części. Każda zawiera 18 wartości. Pierwsza dotyczy wartości instrumentalnych, zaś druga ostatecznych.

Kwestionariusz poziomu mechanizmów obronnych został przygotowany przez autorkę artykułu. Składa się z 19 stwierdzeń. Są one związane $\mathrm{z}$ trzema podskalami. Pierwsza dotyczy mechanizmów prymitywnych, druga wyższych, zaś trzecia dojrzałych. Do całego kwestionariusza została też dołączona 4-punktowa skala.

Badania zostały przeprowadzone w roku 2007 w Wyższej Szkole Filozoficzno-Pedagogicznej „Ignatianum” w Krakowie. Zostało przebadanych 235 studentów studiów zaocznych na kierunkach: pedagogika resocjalizacyjna oraz pedagogika opiekuńczo-wychowawcza.

18 Por. S. Siek, Wybrane metody badania osobowości, Warszawa 1993, s. 173-183. 


\section{Wyniki badań własnych}

Aby przedstawić wyniki badań zostaną wykorzystane dwie metody statystyczne. Pierwsza z nich to metoda analizy różnic istotnych, zaś druga to analiza regresji wielokrotnej. Zmiennymi zależnymi są mechanizmy obronne dojrzałe. Zmiennymi zaś niezależnymi wartości ostateczne i instrumentalne oraz potrzeby. Wartości instrumentalne są następujące: ambicja (1), czystość (2), gotowość kochania (3), grzeczność (4), logiczność myślenia (5), lojalność (6), odpowiedzialność (7), odwaga (8), opanowanie (9), pomysłowość (10), postuszeństwo (11), refleksyjność (12), samodzielność (13), tolerancja (14), uczciwość (15), uczynność (16), wytrwałość (17) oraz zdolność (18). Wartości ostateczne to: bezpieczeństwo narodowe (1), dojrzała miłość (2), madrość (3), piękno świata (4), pokój na świecie (5), prawdziwa przyjaźń (6), przyjemność życia (7), równość ludzi (8), sukcesy życiowe (9), szacunek dla siebie (10), uznanie społeczne (11), wewnętrzny spokój i harmonia (12), wolność osobista (13), wygodne życie (14), zabezpieczenie bytu dla rodziny (15), zbawienie (16), zdrowie (17) i życie petne wrażeń (18). Do potrzeb należą następujące: dominowania (1), uległości (2), autonomii (3), agresywności (4), poniżania się (5), wyczynu (6), seksualna (7), przyjemnych doznań zmysłowych (8), ekshibicjonizmu (9), zabawy (10), odrzucania czyli izolacji (11), stowarzyszania (12), doznawania opieki i oparcia (13), żywienia i opiekowania się kimś (14), bezpieczeństwa jako unikania ponizania we własnych oczach (15), bezpieczeństwa jako unikania urazu ze strony innych ludzi (16), kompensacji (17), bezpieczeństwa jako unikania urazu fizycznego (18) oraz poznawcza (19). W celu przeprowadzenia analizy różnic istotnych testem $\mathrm{T}$ grupa badana została podzielona na dwie. Pierwsza $\mathrm{z}$ nich to grupa z małym nasileniem mechanizmów obronnych dojrzałych (1-4 steny). Osób w grupie jest 57. Druga zaś to osoby z dużym nasileniem mechanizmów obronnych dojrzałych (7-10 stenów). Jest ich 60.

\subsection{Powiązanie między mechanizmami obronnymi dojrzalymi i potrzebami u badanych}

Różnice istotne w intensywności potrzeb u osób z małym natężeniem mechanizmów dojrzałych oraz osób z dużym natężeniem mechanizmów dojrzałych pokazuje wykres 1 .

Najbardziej intensywną potrzebą dla osób z małym nasileniem mechanizmów obronnych dojrzałych jest potrzeba ekshibicjonizmu, zaś najmniej intensywną jest potrzeba żywienia i opiekowania się. Najbardziej intensyw- 
ną potrzebą dla osób z dużym nasileniem dojrzałych mechanizmów obronnych jest potrzeba poznawcza. Najmniej intensywną zaś potrzeba doznawania opieki i oparcia.

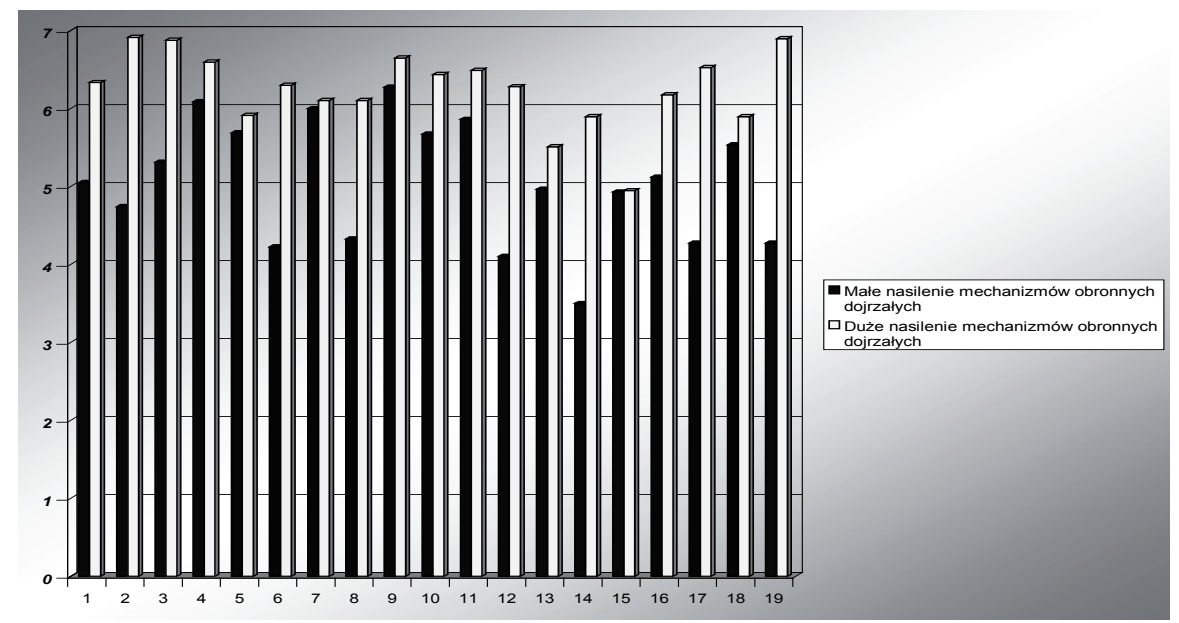

Wykres 1. Intensywność potrzeb a nasilenie dojrzałych mechanizmów obronnych Źródło: badania własne.

Różnice istotne występują w przypadku jedenastu potrzeb. Osoby z dużym natężeniem mechanizmów obronnych dojrzałych charakteryzują się większą intensywnością niż osoby z małym nasileniem mechanizmów obronnych dojrzałych następujących potrzeb: dominowania $(\mathrm{F}=-3,236, \mathrm{p}=0,001)$, uległości $(\mathrm{F}=-5,746, \mathrm{p}=0,000)$, autonomii $(\mathrm{F}=-3,732, \mathrm{p}=0,000)$, wyczynu $(\mathrm{F}=-4,546, \mathrm{p}=0,000)$, przyjemnych doznań zmystowych $(\mathrm{F}=-4,258, \mathrm{p}=0,000)$, zabawy $(\mathrm{F}=-2,004, \mathrm{p}=0,047)$, stowarzyszania $(\mathrm{F}=-4,924, \mathrm{p}=0,000)$, żywienia i opiekowania sie $(\mathrm{F}=-5,535, \mathrm{p}=0,000)$, unikania urazu ze strony innych $(\mathrm{F}=-2,742, \mathrm{p}=0,007)$, kompensacji $(\mathrm{F}=-6,447, \mathrm{p}=0,000)$ oraz poznawczej $(\mathrm{F}=-6,982, \mathrm{p}=0,000)$.

Tabela 1 pokazuje powiązanie pomiędzy mechanizmami obronnymi dojrzałymi i nasileniem potrzeb dla całej grupy badanych.

Trzy potrzeby mają istotny wpływ na intensywność mechanizmów obronnych dojrzałych. Są to potrzeby: żywienia i opiekowania się $(\mathrm{p}=0,014)$, kompensacji $(\mathrm{p}=0,028)$ oraz poznawcza $(\mathrm{p}=0,000)$. Wyjaśniają one $40 \%$ zmienności mechanizmów obronnych dojrzałych. Związek jest dodatni. Oznacza to, że im większa intensywność potrzeb żywienia i opiekowania się, kompensacji i poznawczej, tym większe nasilenie mechanizmów obronnych dojrzałych. 
Tabela 1. Istotne zmienne niezależne dotyczące potrzeb i wyjaśniające wariancję mechanizmów obronnych dojrzałych. Wyniki regresji wielokrotnej dla całej grupy badanych. Źródło: badania własne.

\begin{tabular}{|l|l|l|l|l|}
\hline Zmienne & BETA & B & t & poziom p \\
\hline Zależna: Mechanizmy dojrzale & & & & \\
\hline $\begin{array}{l}\text { Niezależne: Potrzeba żywienia } \\
\text { i opiekowania się }\end{array}$ & 0,215903 & 0,179338 & 2,45438 & 0,014908 \\
\hline Potrzeba kompensacji & 0,165099 & 0,146125 & 2,20629 & 0,028423 \\
\hline Potrzeba poznawcza & 0,352200 & 0,328107 & 5,10868 & 0,000001 \\
\hline
\end{tabular}

Podsumowanie regresji zmiennej zależnej: NowaZm10 (Arkusz7) R= ,63269957 $\mathrm{R} 2=, 40030874$ Skoryg. $\mathrm{R} 2=, 34731277 \mathrm{~F}(19,215)=7,5536 \mathrm{p}$

\subsection{Powiązanie pomiędzy mechanizmami obronnymi dojrzałymi i wartościami instrumentalnymi u badanych}

Istotne różnice w preferowaniu wartości instrumentalnych przez osoby mające małe nasilenie mechanizmów obronnych dojrzałych i osoby mające duże nasilenie mechanizmów obronnych dojrzałych pokazuje wykres 2 .

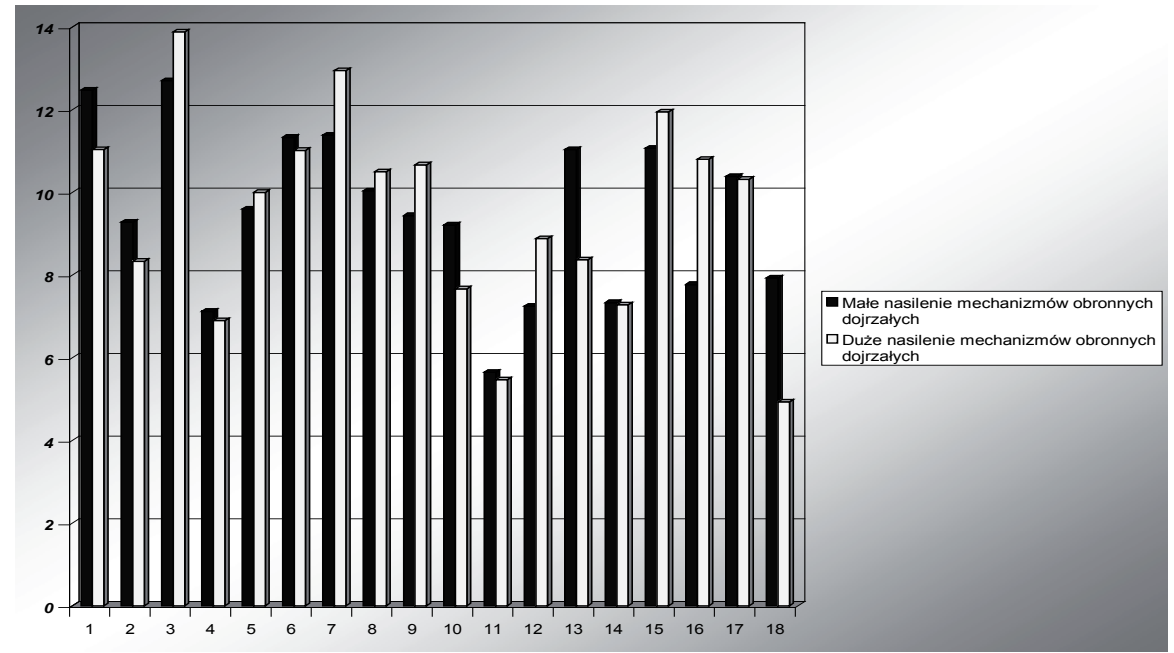

Wykres 2. Średnia rang wartości instrumentalnych a nasilenie mechanizmów obronnych dojrzałych. Źródło: badania własne. 
Najbardziej cenioną wartością instrumentalną przez osoby z małym nasileniem mechanizmów obronnych dojrzałych jest gotowość kochania, a najmniej postuszeństwo. Najbardziej zaś cenioną wartością instrumentalną przez osoby o dużym nasileniu mechanizmów obronnych dojrzałych jest gotowość kochania, a najmniej zdolność.

Różnice istotne występują w przypadku czterech rang. Osoby z dużym nasileniem mechanizmów obronnych dojrzałych cenią sobie wyżej niż osoby z małym nasileniem mechanizmów obronnych dojrzałych następujące wartości instrumentalne: refleksyjność $(\mathrm{F}=-2,200, \mathrm{p}=0,029)$ i uczynność $(\mathrm{F}=-3,158, \mathrm{p}=0,002)$. Osoby z małym nasileniem mechanizmów obronnych dojrzałych cenią zaś sobie wyżej niż osoby z dużym nasileniem mechanizmów obronnych dojrzałych takie wartości instrumentalne jak: samodzielność $(\mathrm{F}=3,261, \mathrm{p}=0,001)$ oraz $z$ dolność $(\mathrm{F}=3,615, \mathrm{p}=0,000)$.

$\mathrm{W}$ toku badań stwierdzono, iż nie występują żadne istotne związki pomiędzy nasileniem mechanizmów obronnych dojrzałych i wartościami instrumentalnymi w badanej grupie.

\subsection{Powiązanie pomiędzy nasileniem mechanizmów obronnych dojrzałych i wartościami ostatecznymi}

Istotne różnice w preferowaniu wartości ostatecznych w zależności od nasilenia mechanizmów obronnych dojrzałych pokazuje wykres 3 .

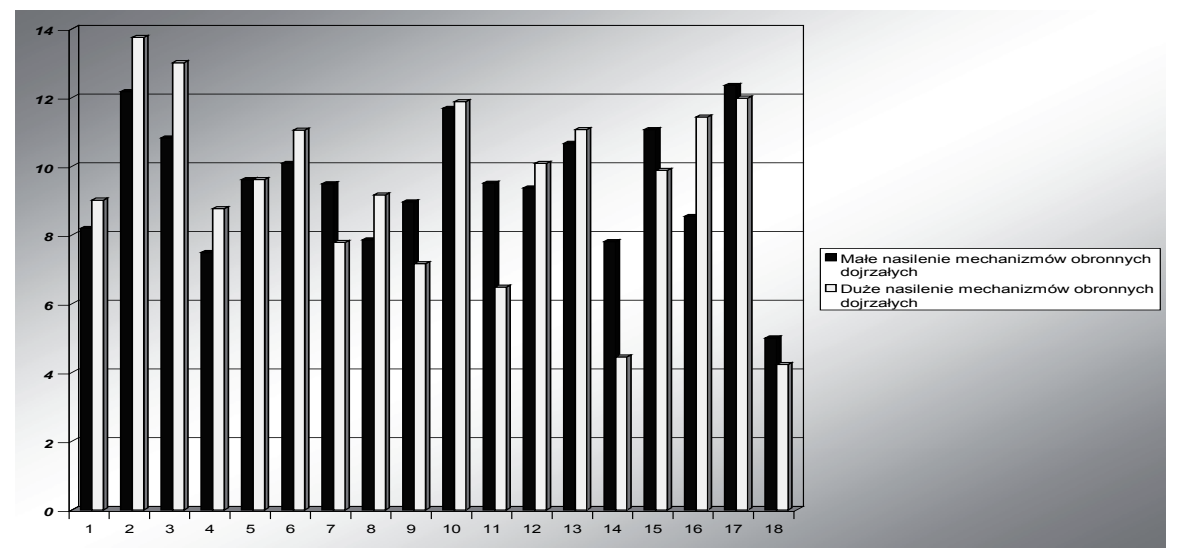

Wykres 3. Średnie rang wartości ostatecznych a nasilenie mechanizmów obronnych dojrzałych. Źródło: badania własne.

Osoby z małym nasileniem mechanizmów obronnych dojrzałych najbardziej sobie cenią jako wartość zdrowie, zaś najmniej życie petne wrażeń. 
Osoby zaś z dużym nasileniem mechanizmów obronnych dojrzałych najbardziej cenią sobie jako wartość dojrzała miłość, zaś najmniej życie petne wrażeń.

Różnice istotne statystycznie notuje się w czterech rangach. Osoby z dużym nasileniem mechanizmów obronnych dojrzałych bardziej niż osoby z małym nasileniem mechanizmów obronnych dojrzałych preferują takie wartości ostateczne, jak: madrość $(\mathrm{F}=-2,416, \mathrm{p}=0,017)$ i zbawienie $(\mathrm{F}=-2,527, \mathrm{p}=0,012)$. Osoby z małym nasileniem mechanizmów obronnych dojrzałych wyżej sobie cenią niż osoby z dużym nasileniem mechanizmów obronnych dojrzałych takie wartości ostateczne, jak: uznanie społeczne $(\mathrm{F}=3,482, \mathrm{p}=0,000)$ oraz wygodne życie $(\mathrm{F}=3,728, \mathrm{p}=0,000)$.

W toku badań stwierdzono, że nie ma istotnego powiązania między mechanizmami obronnymi dojrzałymi oraz wartościami ostatecznymi w badanej grupie osób.

\section{Analiza psychologiczna}

Wykres 4 opisuje, które potrzeby są bardziej intensywnymi u osób z małym nasileniem mechanizmów obronnych dojrzałych, a które są bardziej zintensyfikowane u osób z ich dużym nasileniem.

Małe nasilenie

Duże nasilenie

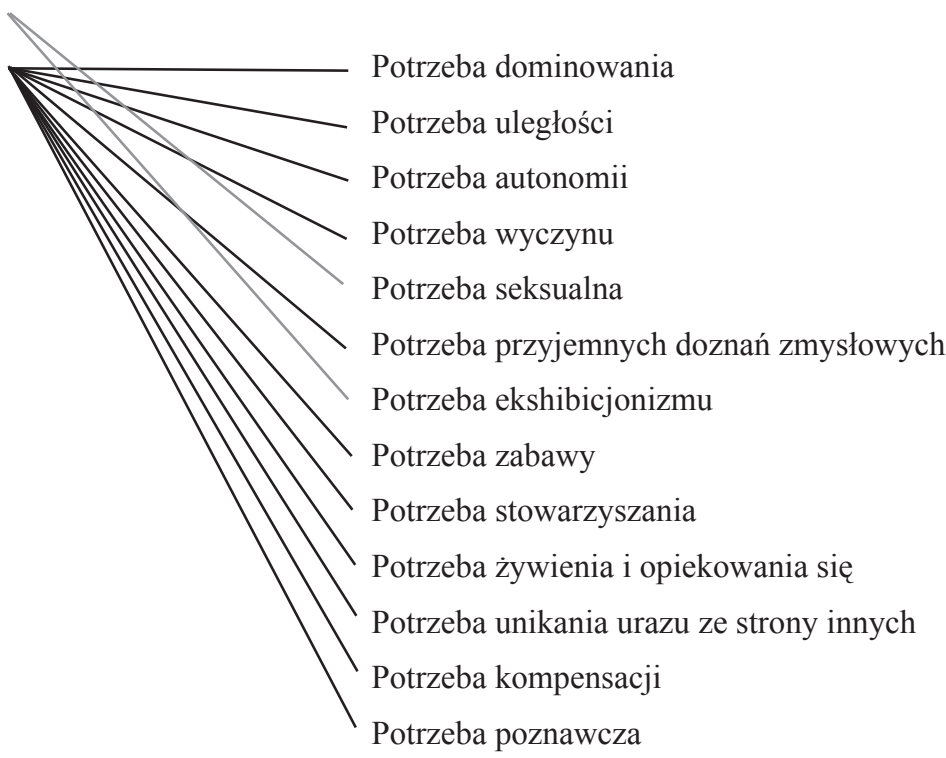

Wykres 4. Intensywność potrzeb u osób z małym i dużym nasileniem mechanizmów obronnych dojrzałych. Źródło: badania własne. 
Przy badaniu powiązania mechanizmów obronnych dojrzałych z potrzebami stwierdzono istotny związek dodatni pomiędzy mechanizmami obronnymi dojrzałymi i trzema spośród potrzeb, które w istotny sposób są preferowane bardziej przez osoby mające duże nasilenie mechanizmów obronnych dojrzałych. Są to potrzeby: żywienia i opiekowania się, kompensacji i poznawcza.

Wykres 5 pokazuje, które z wartości instrumentalnych są bardziej preferowane przez osoby mające małe nasilenie mechanizmów obronnych dojrzałych, a które przez osoby mające duże nasilenie mechanizmów obronnych dojrzałych.

Małe nasilenie

Duże nasilenie

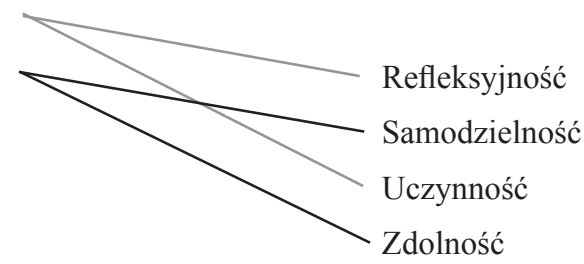

Wykres 5. Preferowanie wartości instrumentalnych u osób z małym i dużym nasileniem mechanizmów obronnych dojrzałych. Źródło: badania własne.

Jak widać, osoby o dużym nasileniu mechanizmów obronnych dojrzałych bardziej preferują takie wartości, jak refleksyjność i uczynność.

Wykres 6 opisuje, które z wartości ostatecznych są bardziej preferowane przez osoby mające małe nasilenie mechanizmów obronnych dojrzałych, a które przez osoby mające duże nasilenie mechanizmów obronnych dojrzałych.

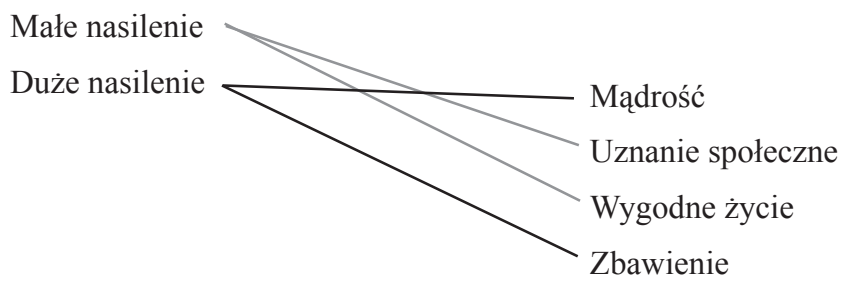

Wykres 6. Preferowanie wartości ostatecznych u osób z małym i dużym nasileniem mechanizmów obronnych dojrzałych. Źródło: badania własne.

W tym przypadku również nie zanotowano istotnych powiązań pomiędzy mechanizmami obronnymi dojrzałymi i wartościami ostatecznymi. Widać jednak z wykresu, iż osoby z dużym nasileniem mechanizmów obron- 
nych dojrzałych bardziej preferują takie wartości ostateczne jak mqdrość i zbawienie.

\section{Weryfikacja hipotez}

Można stwierdzić, że sprawdziła się hipoteza, iż przypuszcza się, że mechanizmy obronne dojrzałe maja znaczenie $w \dot{z} y c i u$ przyszłych pedagogów. Rzeczywiście można powiedzieć, iż wyniki badań potwierdzają, że mechanizmy obronne dojrzałe mają istotne znaczenie w życiu przyszłych pedagogów.

Hipoteza, że podejrzewa się, że mechanizmy obronne dojrzałe maja zwiqzek z intensywnościq potrzeb u przyszłych pedagogów również sprawdziła się w pełni. Istnieje aż jedenaście potrzeb, których nasilenie różni się w istotny sposób u osób mających małe oraz u osób mających duże nasilenie mechanizmów obronnych dojrzałych. Poza tym istnieje istotny związek dodatni pomiędzy mechanizmami obronnymi dojrzałymi i potrzebami: $\dot{z y w i e-}$ nia i opiekowania sie, kompensacji i poznawcza.

Hipoteza, że zakłada się, że mechanizmy obronne dojrzałe maja zwiqzek z preferencja wartości u przyszłych pedagogów sprawdziła się częściowo. Można powiedzieć i w wypadku wartości instrumentalnych, i w wypadku wartości ostatecznych o czterech rangach, w których notuje się różnice istotne pomiędzy osobami, które mają małe nasilenie mechanizmów obronnych dojrzałych oraz mającymi duże nasilenie mechanizmów obronnych dojrzałych. Jednak nie istnieje istotny wpływ mechanizmów obronnych dojrzałych na wartości ostateczne i instrumentalne.

\section{Zestawienie wyników z literaturą przedmiotu}

Literatura podaje wartości, które najczęściej wybierająjako ważne przyszli pedagodzy. Niektórzy z nich jako szczególnie istotne podają takie wartości jak: zbawienie, wiara i religia ${ }^{19}$. Inne badania jako szczególnie cenione wartości przez studentów pedagogiki podają: udane życie rodzinne, wiedzę i wykształcenie ${ }^{20}$. Tucholska w swoich badaniach stwierdza, iż osoby charakteryzujące się ambicjonalnym dążeniem do sukcesów oraz skłonnością

19 Por. B. Wolny, Wartości życia człowieka w opinii studentów pedagogiki, w: J. Kostkiewicz (red.), Aksjologia w kształceniu pedagogów, Kraków 2008, s. 251-266.

${ }^{20}$ Por. W. Wróblewska, Autoedukacja studentów w kontekście preferowanych wartości, w: J. Kostkiewicz (red.), dz. cyt., s. 275-284. 
do rywalizacji, a więc preferujące wartość ambicji, charakteryzują się też większą podatnością na wypalenie zawodowe ${ }^{21}$. Zarówno refleksyjność, jak i uczynność są również wymieniane w literaturze pedagogicznej ${ }^{22}$.

Badania prezentowane w literaturze podkreślają znaczenie dla pedagoga dużej intensywności takich potrzeb, jak potrzeba: żywienia i opiekowania się oraz stowarzyszania ${ }^{23}$. Mówią też o potrzebach: kompensacji oraz poznawczej ${ }^{24}$.

Literatura podkreśla znaczenie, jakie ma korzystanie z dojrzałych mechanizmów obronnych w zawodzie pedagoga ${ }^{25}$. Pokazuje, iż pedagog określany jako dojrzały i szczęśliwy, a więc mający poczucie humoru i zadowolony z pracy, jest mniej narażony na syndrom zawodowego wypalenia ${ }^{26}$.

Niniejsze badania potwierdzily dane z literatury. Pokazały również, iż potrzeby mające szczególne znaczenie dla pedagogów oraz wartości przez nich preferowane oraz wymieniane przez literaturę jako dla nich ważne, są powiązane $\mathrm{w}$ znaczącym stopniu $\mathrm{z}$ dużą intensywnością dojrzałych mechanizmów obronnych.

\section{Wnioski pedagogiczne}

Wyniki powyższe mogą mieć duże znaczenie w przygotowaniu pedagogów do ich aktywności zawodowej. Potrzeba żywienia i opiekowania się jest niewątpliwie uważana za bardzo ważną dla pedagoga. Niestety, jak pokazuje Olubiński na podstawie badań, wcale nie jest często spotykana u pedagogów i w zawodach pokrewnych jako potrzeba dominująca ${ }^{27}$. Opierając się na wynikach badań, można by sądzić, iż osoby posługujące się mechanizmami obronnymi dojrzałymi mają większą intensywność takiej potrzeby.

Nie dziwi bardzo, iż pojawia się też dodatni związek mechanizmów obronnych dojrzałych z potrzebą kompensacji, która jest mocno związana $\mathrm{z}$ pragnieniem rozwoju i pokonywaniem własnych ograniczeń. Widać, iż takie cechy są też powiązane z dojrzałością stosowanych mechanizmów obronnych.

${ }^{21}$ Por. St. Tucholska, Wypalenie zawodowe u nauczycieli, Lublin 2003, s. 133-148.

${ }^{22}$ Por. J. Kostkiewicz (red.), Aksjologia w ksztatceniu pedagogów, Kraków 2008.

${ }^{23}$ Por. A. Olubiński, Praca socjalna. Aspekty humanistyczne i pedagogiczne, Toruń 2004, s. 51-57.

${ }^{24}$ Por. St. Tucholska, dz. cyt., s. 19-20.

${ }^{25}$ Por. tamże, s. 207-227.

${ }^{26}$ Por. M. Sekułowicz, dz. cyt., s. 77-136.

27 Por. A. Olubiński, dz. cyt., s. 51-57. 
Jak widać, również mechanizmy obronne dojrzałe mają związek dodatni z potrzebą poznawcza, która jest istotna dla przyszłego pedagoga.

Można więc powiedzieć, iż osoby, które korzystają często z mechanizmów obronnych dojrzałych, mają większe nasilenie potrzeb bardzo istotnych w zawodzie pedagoga, takich jak potrzeby: żywienia i opiekowania się, kompensacji i poznawcza.

Nie ma wprawdzie żadnych istotnych związków pomiędzy mechanizmami obronnymi dojrzałymi i wartościami instrumentalnymi, ale widać, iż wartości instrumentalne, które są w istotny sposób wyżej cenione przez osoby z dużym nasileniem mechanizmów obronnych dojrzałych, to wartości podkreślane jako istotne w pracy pedagoga. Pokazuje to znowu, jak ważne znaczenie mają mechanizmy obronne dojrzałe w zawodzie pedagoga.

Trzeba również zauważyć, iż wartości preferowane w istotny sposób bardziej przez osoby z małym nasileniem mechanizmów obronnych dojrzałych, to wartości zaliczane do materialnych, zaś wartości preferowane w istotny sposób przez osoby z dużym nasileniem mechanizmów obronnych dojrzałych, to wartości wymieniane przez literaturą jako istotne dla pedagoga.

Widać więc u przyszłych pedagogów duże znaczenie umiejętności korzystania z mechanizmów obronnych dojrzałych, takich jak: asceza, thumienie, humor, altruizm czy też sublimacja.

Analiza materiału badawczego nasuwa kilka związków praktycznych:

- rozwijanie u przyszłych pedagogów umiejętności altruizmu, poczucia humoru czy sublimacji może pomagać w rozwoju opiekuńczości i empatii,

- rozwijanie tych mechanizmów ma również związek z potrzebami kompensacji i poznawczą. $Z$ tego wynika, że rozwijanie tych mechanizmów obronnych będzie miało u studentów związek z ich umiejętnością pokonywania trudności oraz pragnieniem zdobywania wiedzy, rozszerzania swoich horyzontów,

- rozwijanie mechanizmów altruizmu, sublimacji czy też poczucia humoru może być ważne dla wybierania przez te osoby wartości bardziej nakierowanych na relacje $\mathrm{z}$ innymi, a więc istotnych w zawodzie pedagoga.

\section{Podsumowanie}

Podsumowując, można powiedzieć, że rzeczywiście mechanizmy obronne dojrzałe są istotne w pracy przyszłego pedagoga. Nie jest więc obojętne, czy taka osoba potrafi wykazać się poczuciem humoru, czy potrafi odraczać gratyfikację swoich potrzeb, czy potrafi sublimować swoje popędy. Nie jest też obojętne, czy charakteryzuje się skłonnością do altruizmu, czy też zajmuje się jedynie sobą. Dlatego też warto obserwować, jakimi mecha- 
nizmami obronnymi posługują się przyszli pedagodzy, bo może to w jakiś sposób wskazywać na ich dojrzałość do zawodu oraz na potrzeby i wartości, które ich charakteryzują.

Obecny artykuł nie wyczerpuje podjętej tematyki. Ważne byłoby przeprowadzenie badań dotyczących dojrzałych mechanizmów obronnych również wśród studentów innych kierunków. Być może ciekawe byłoby przeprowadzenie takich badań wśród studentów kierunków nauczycielskich, czy też przygotowujących się do wykonywania zawodów pomocowych, jak na przykład lekarz, pielęgniarka, psycholog, czy też psychoterapeuta.

\section{The Relationship Between Mature Defenses vs. Needs and Values of Prospective Pedagogues (Summary)}

The role of defense mechanisms is to safeguard a person's ego. They help defend him or herself against fear. Every person makes use of an array of more or less mature defenses. Mature defenses facilitate to pursue the profession of pedagogue. This article presents research which explores the relationship between mature defenses, on the one hand, and needs and values of prospective pedagogues, on the other. 